\title{
Adult Pre-B Acute Lymphoblastic Leukemia
}

National Cancer Institute

\section{Source}

National Cancer Institute. Adult Pre-B Acute Lymphoblastic Leukemia. NCI Thesaurus.

Code C114599.

Pre-B acute lymphoblastic leukemia that occurs during adulthood. 